\title{
POLA PENGOBATAN PASIEN LEUKEMIA LIMFOBLASTIK AKUT DI RSUD ABDUL WAHAB SJAHRANIE SAMARINDA
}

\author{
Annisa Lufritayanti ${ }^{1 *}$, Jaka Fadraersada ${ }^{1}$, Muh. Amir Masruhim ${ }^{2}$ \\ ${ }^{1}$ Fakultas Farmasi Universitas Mulawarman, Samarinda \\ ${ }^{2}$ Fakultas Keguruan dan Ilmu Pengetahuan Universitas Mulawarman, Samarinda \\ *email: annisalufritayanti@gmail.com
}

\begin{abstract}
ABSTRAK
Leukemia Limfoblastik Akut (LLA) adalah keganasan sel yang terjadi akibat proliferasi sel limfoid yang diblokir pada tahap awal diferensiasinya. LLA adalah kanker paling umum yang terjadi pada anak-anak. Telah dilakukan penelitian Pola Pengobatan Pasien Leukemia Limfoblastik Akut di RSUD Abdul Wahab Sjahranie Samarinda. Penelitian ini bertujuan untuk mengetahui karakteristik pasien, pola pengobatan dan efek samping pengobatan LLA pada periode 2014-2015. Penelitian ini merupakan penelitian deskriptif evaluatif dengan metode retrospektif. Teknik pengambilan data secara total sampling didapatkan sebanyak 21 kasus. Hasil penelitian menunjukkan bahwa pasien LLA paling banyak diderita oleh lakilaki sebanyak 13 kasus (62\%). Berdasarkan usia yang paling banyak menderita LLA dengan usia 0-4 tahun sebanyak 10 kasus (48\%). Tipe LLA yang banyak diderita pasien adalah LLA tipe $\mathrm{L}_{1}$ sebanyak 13 kasus (62\%). Pola pengobatan LLA berdasarkan pemilihan jenis dan golongan obat kemoterapi terbanyak adalah obat kemoterapi Vincristine sebanyak 4 kasus (19\%) dan kombinasi obat kemoterapi Vincristine-Methotrexate IT sebanyak 4 kasus (19\%). Berdasarkan pemilihan jenis dan golongan obat adjuvan terbanyak adalah obat Deksametason sebanyak 5 kasus (24\%). Adapun berdasarkan efek samping obat kemoterapi terbanyak adalah mual muntah-anemia sebanyak 4 kasus (19\%).
\end{abstract}

Kata Kunci : efek samping, karakteristik, LLA, pola pengobatan

\section{ABSTRACT}

Acute Lymphoblastic Leukemia (ALL) is a malignancy of cells that occurs as a result of the proliferation of lymphoid cells blocked at an early stage differentiation. ALL is the most common cancer that occurs in children. Has been done study Treatment Patterns of Acute Lymphoblastic Leukemia Patients in Abdul Wahab Sjahranie Hospital Samarinda. This study aims to determine characteristics, treatment patterns and side effects of treatment of ALL patients in the period 2014-2015. This is a descriptive evaluative study with retrospective method. Data collection techniques by total sampling obtained 21 cases. Results showed that ALL patients most suffered by males are 13 cases (62\%). Based on the age that suffered most ALL is age 0-4 years in 10 cases (48\%). ALL type that affects many ALL patients is ALL type $L_{1}$ in 13 cases (62\%). LLA treatment patterns by selecting the type and class of chemotherapy drugs most used are chemotherapy drug Vincristine in 4 cases (19\%) and combination of chemotherapy drugs Vincristine-Methotrexate IT in 4 cases (19\%). Based on the selection of the type and class of adjuvant drugs most used is Dexamethasone in 5 cases (24\%). As based on the side effect of chemotherapy drugs that happen the most is nausea vomiting-anemia in 4 cases (19\%).

Keywords : ALL, characteristics, side effects, treatment patterns 


\section{PENDAHULUAN}

Leukemia Limfoblastik Akut (LLA) adalah keganasan sel yang terjadi akibat proliferasi sel limfoid yang diblokir pada tahap awal deferensiasinya. LLA merupakan kanker dengan angka kejadian yang paling tinggi pada anak, 75\% terjadi pada anak di bawah 6 tahun. Pengobatan dengan kemoterapi merupakan terapi kuratif utama pada leukemia (Pertiwi, 2013).

LLA adalah tipe kanker darah. Nama lain untuk LLA adalah 'leukemia limfositik akut" dan "leukemia limfoid akut". LLA merupakan tipe leukemia paling umum pada anakanak (LLS, 2014).

Berdasarkan data GLOBOCAN, International Agency for Research on Cancer (IARC), diketahui bahwa persentase kasus baru leukemia di dunia yaitu sebesar 4,7\% (Kemenkes RI, 2015). LLA bertanggung jawab sekitar 25\% dari semua kanker pada anak dan sekitar $80 \%$ dari leukemia pada anak. Tingkat kejadian tahunan LLA bervariasi di seluruh dunia antara sekitar satu dan empat kasus baru per 100.000 anak-anak dibawah usia 15 tahun, dengan kejadian puncak pada usia sekitar dua sampai lima tahun (ENCCA, 2011). Di Indonesia saat ini terdapat sekitar 80.000.000 anak dibawah usia 15 tahun. Diperkirakan ada sekitar 3000 kasus LLA baru anak setiap tahunnya. Sebagai negara berkembang Indonesia menghadapi masalah yang sama dengan negara berkembang yang lain, seperti sistem pelaporan yang masih belum baik, malnutrisi, infeksi, biaya protokol pengobatan dan pengobatan suportif yang minimal.

LLA adalah tipe kanker yang dimulai di sumsum tulang. Seseorang bisa terkena LLA pada usia berapapun. Keseluruhan risiko terkena LLA kecil untuk anak-anak dan orang dewasa. Namun, LLA tetap menjadi jenis kanker yang paling umum pada anak di bawah usia 15. Risiko orang dewasa terkena LLA meningkat pada orang usia 50 dan lebih tua (LLS, 2014).

Oleh karena itu maka penelitian mengenai pola pengobatan LLA perlu dilakukan untuk mendapatkan data jumlah dan persentase pasien LLA dan mengetahui gambaran kajian karakteristik, pola pengobatan serta efek samping dan penanganannya pada pasien LLA di RSUD Abdul Wahab Sjahranie Samarinda.

\section{METODE PENELITIAN}

Penelitian ini menggunakan metode deskriptif evaluatif dan analisis data secara retrospektif dengan melihat status Rekam Medik Kesehatan (RMK) pasien LLA di Instalasi Rawat Inap RSUD Abdul Wahab Sjahranie Samarinda. Data yang diambil dari sejumlah pasien rawat inap yang didiagnosis menderita LLA dengan periode 2014-2015. Jumlah keseluruhan sampel adalah 21 pasien dengan diagnosa terakhir LLA serta mempunyai data rekam medik yang lengkap.

Proses pengambilan data pada penelitian ini dilakukan dengan observasi umum rekam medik pasien LLA periode 2014-2015. Kemudian ditetapkan sampel yang ingin diteliti, selanjutnya dilakukan pencatatan atau pengumpulan data. Setelah itu data dianalisis dan dibuat tabulasi data. 


\section{HASIL DAN PEMBAHASAN}

\section{Karakteristik Pasien}

Tabel 1. Tabel Distribusi Jenis Kelamin Pasien LLA di Instalasi Rawat Inap RSUD A.W

Sjahranie Samarinda periode 2014-2015

\begin{tabular}{ccc}
\hline Jenis kelamin & Jumlah pasien & Persentase (\%) \\
\hline Laki-laki & 13 & $62 \%$ \\
Perempuan & 8 & $38 \%$ \\
Total & 21 & $100 \%$ \\
\hline
\end{tabular}

Tabel 1 menunjukkan persentase penderita LLA berdasarkan jenis kelamin selama periode 2014-2015. Dari 21 kasus LLA yang menjalani rawat inap di RSUD Abdul Wahab Sjahranie Samarinda sebanyak 62\% atau 13 pasien berjenis kelamin laki-laki dan 38\% atau 8 pasien berjenis kelamin perempuan. Hal ini menunjukkan bahwa jumlah penderita LLA laki-laki lebih besar daripada perempuan. Hal ini dapat dikaitkan dengan keberadaan gen "seks-responsif" dekat lokus gen ABO pada kromosom 9. Selain itu, laki-laki dapat lebih banyak terpapar karsinogen, memiliki perbedaan hormonal atau metabolisme, atau kurang mendapat perlindungan dari antioksidan daripada perempuan.

Tabel 2. Tabel Distribusi Umur Pasien LLA di Instalasi Rawat Inap RSUD A.W Sjahranie Samarinda periode 2014-2015

\begin{tabular}{ccc}
\hline Usia (tahun) & Jumlah Pasien & Persentase (\%) \\
\hline $0-4$ & 10 & $48 \%$ \\
$5-9$ & 5 & $24 \%$ \\
$10-14$ & 4 & $19 \%$ \\
$\geq 15$ & 2 & $9 \%$ \\
Total & 21 & $100 \%$ \\
\hline
\end{tabular}

Tabel 2 menunjukkan persentase penderita LLA berdasarkan usia diketahui jumlah penderita yang berusia $0-4$ tahun menunjukkan persentase terbesar yaitu $48 \%$ (10 penderita), usia 5-9 tahun sebesar 24\% (5 penderita), usia 10-14 tahun sebesar 19\% (4 penderita) dan usia $\geq 15$ tahun sebesar $9 \%$ ( 2 penderita).

Seseorang bisa terkena LLA pada usia berapapun. Tingkat kejadian puncak LLA pada usia sekitar dua sampai lima tahun (ENCCA, 2011). Penyebab paling tepat kebanyakan kasus LLA tidak diketahui. Sistem kekebalan memainkan peran penting dalam melindungi sistem kekebalan tubuh. Perubahan atau cacat dalam sistem kekebalan tubuh dapat meningkatkan risiko untuk mengembangkan kanker.

Tabel 3. Tabel Distribusi Tipe Pasien LLA di Instalasi Rawat Inap RSUD A.W Sjahranie Samarinda periode 2014-2015

\begin{tabular}{ccc}
\hline Klasifikasi LLA & Jumlah & Persentase \\
\hline Tipe $\mathrm{L}_{1}$ & 13 & $62 \%$ \\
Tipe $\mathrm{L}_{2}$ & 7 & $33 \%$ \\
Tipe $\mathrm{L}_{3}$ & 1 & $5 \%$ \\
Total & 21 & $100 \%$ \\
\hline
\end{tabular}


Tabel 3 menunjukkan persentase tipe LLA yang diderita pasien. Menurut (Ball, 2013) ada tiga subtipe yang berbeda dari LLA, berdasarkan penampilan leukemia, atau sel yang berkembang tidak sempurna. Subtipe ini yaitu $\mathrm{L}_{1}$ (paling umum pada anak-anak), $\mathrm{L}_{2}$ (paling umum pada orang dewasa), dan $\mathrm{L}_{3}$, paling agresif, yang juga disebut Burkitt-seperti leukemia.

Tipe $\mathrm{L}_{1}$ ditandai dengan sel blast berukuran kecil, homogen (relatif sama besar), dengan sitoplasma sel sedikit dan nukleoli yang samar atau tidak jelas. Tipe $\mathrm{L}_{2}$ ditandai dengan sel blast berukuran lebih besar, heterogen (tidak seragam), nukleoli terlihat jelas dan rasio inti-sitoplasmanya rendah. Sedangkan tipe $\mathrm{L}_{3}$ ditandai dengan sel blast besar, sitoplasma bervakoul dan terlihat pekat (basolifik). Dari 21 kasus LLA yang menjalani rawat inap di RSUD Abdul Wahab Sjahranie Samarinda sebanyak 13 kasus (62\%) mengalami LLA tipe $\mathrm{L}_{1}, 7$ kasus (33\%) mengalami LLA tipe $\mathrm{L}_{2}$ dan 1 kasus (5\%) mengalami LLA tipe $\mathrm{L}_{3}$.

\section{Pengobatan Pada Pasien LLA}

Tabel 4. Profil Pengobatan Kemoterapi Pasien LLA di Instalasi Rawat Inap RSUD A.W Sjahranie Samarinda periode 2014-2015

\begin{tabular}{|c|c|c|}
\hline Obat Kemoterapi & Jumlah Pasien & Persentase $(\%)$ \\
\hline Vincristine & 4 & $19 \%$ \\
\hline Vincristine-Daunorubicine & 1 & $5 \%$ \\
\hline Vincristine-Methotrexate IT & 4 & $19 \%$ \\
\hline $\begin{array}{l}\text { Vincristine-Methotrexate IT-Methotrexate } \\
\text { HD-Daunorubicine-L-Asparaginase }\end{array}$ & 2 & $9 \%$ \\
\hline $\begin{array}{l}\text { Vincristine-Methotrexate IT-Methotrexate } \\
\text { HD-Daunorubicine }\end{array}$ & 1 & $5 \%$ \\
\hline $\begin{array}{l}\text { Vincristine-Daunorubicine-Methotrexate } \\
\text { HD-L-Asparaginase }\end{array}$ & 1 & $5 \%$ \\
\hline $\begin{array}{l}\text { Vincristine-Methotrexate IT-Methotrexate } \\
\text { HD-Daunorubicine-L-Asparaginase- } \\
\text { Cyclophosphamide-Citaribine }\end{array}$ & 1 & $5 \%$ \\
\hline
\end{tabular}

Tabel 4 menunjukkan persentase pengobatan kemoterapi yang dijalani pasien. Dari 21 kasus LLA yang menjalani rawat inap di RSUD A. W. Sjahranie Samarinda terdapat 4 kasus (19\%) menggunakan Vincristine, 4 kasus (19\%) menggunakan Vincristine-Methotrexate IT, 2 kasus (9\%) menggunakan Vincristine-Methotrexate IT-Methotrexate HD-DaunorubicineL-Asparaginase, 1 kasus (5\%) menggunakan Vincristine-Daunorubicine, 1 kasus (5\%) menggunakan Vincristine-Methotrexate IT-Methotrexate HD-Daunorubicine, 1 kasus (5\%) menggunakan Vincristine-Daunorubicine-Methotrexate HD-L-Asparaginase dan 1 kasus (5\%) menggunakan Vincristine-Methotrexate IT-Methotrexate HD-Daunorubicine-LAsparaginase-Cyclophosphamide-Citaribine.

Alkaloid vinca adalah agen antimitosis yang diturunkan dari tanaman Vinca rosea; aktivitas sitotoksik berhubungan dengan mengikat khusus ke mikrotubula tubulin protein, menyebabkan disolusi mikrotubulus. Vinca mematikan untuk sel pada konsentrasi tinggi; pada konsentrasi rendah, sel-sel ditangkap di porsi metafase mitosis. Metotreksat adalah analog asam folat yang mengikat dihidrofolat reduktase, menghalangi pembentukan DNA nukleosida timidin, sintesis purin juga dilarang (Anderson, 2002). 
Tabel 5. Profil Pengobatan Adjuvan Pasien LLA di Instalasi Rawat Inap RSUD A.W Sjahranie Samarinda periode 2014-2015

\begin{tabular}{ccc}
\hline Obat Adjuvan & Jumlah Pasien & Persentase (\%) \\
\hline Dexamethasone & 5 & $24 \%$ \\
Prednisone & 1 & $5 \%$ \\
Prednisone-Leucovorin & 1 & $5 \%$ \\
Dexamethasone-Leucovorin & 1 & $5 \%$ \\
\hline
\end{tabular}

Tabel 5 menunjukkan persentase pengobatan adjuvan yang dijalani pasien. Dari 21 kasus LLA yang menjalani rawat inap di RSUD A.W. Sjahranie Samarinda terdapat 5 kasus (24\%) menggunakan Dexamethasone, 1 kasus (5\%) menggunakan Prednisone, 1 kasus (5\%) menggunakan Prednisone-Leucovorin dan1 kasus (5\%) menggunakan DexamethasoneLeucovorin.

Dexamethasone merupakan kortikosteroid yang mengurangi agen inflamasi dalam tubuh yang dapat berkontribusi pada pertumbuhan atau perkembangan beberapa jenis kanker. Dexamethasone adalah agen steroid dengan bentuk lebih kuat daripada prednisone.

Tabel 6. Profil Efek Samping Pengobatan Kemoterapi Pasien LLA di Instalasi Rawat Inap RSUD A.W Sjahranie Samarinda periode 2014-2015

\begin{tabular}{ccc}
\hline Efek Samping Obat & Jumlah Pasien & Persentase (\%) \\
\hline Mual Muntah & 3 & $14 \%$ \\
Anemia & 2 & $9 \%$ \\
Mual Muntah-Anemia & 4 & $19 \%$ \\
Anemia-Stomatitis & 1 & $5 \%$ \\
Anemia-Trombositopenia & 1 & $5 \%$ \\
Anemia-Mual Muntah-Diare & 1 & $5 \%$ \\
\hline
\end{tabular}

Tabel 6 menunjukkan persentase efek samping pengobatan kemoterapi yang dialami pasien. Dari 21 kasus LLA yang menjalani rawat inap di RSUD A. W. Sjahranie Samarinda terdapat 3 kasus (14\%) mengalami mual muntah, 2 kasus (9\%) mengalami anemia, 4 kasus (19\%) mengalami mual muntah-anemia, 1 kasus (5\%) mengalami anemia-stomatitis, 1 kasus (5\%) mengalami anemia-trombositopenia dan 1 kasus (5\%) mengalami anemia-mual muntah-diare. Hal ini dapat disimpulkan bahwa efek samping obat yang terjadi pada pasien LLA yaitu mayoritas mual muntah-anemia.

Mual muntah sering muncul bersama dalam berbagai kondisi, termasuk menjadi efek samping yang umum terjadi pada penggunaan obat anti neoplastik. Anemia merupakan komplikasi yang sering terjadi pada penderita kanker. Menurut (Azmi, 2005) beberapa faktor yang mengakibatkan anemia antara lain yaitu kehilangan darah (pendarahan) akut ataupun kronik, pendarahan dalam tumor sendiri, anemia karena proses fagositosis dari eritrosit, penggantian sumsum tulang. Hal ini karena kanker mempengaruhi sel-sel darah merah dan hemoglobin tubuh mengurangi kemampuan darah untuk mengangkut oksigen yang diperlukan ke jaringan tubuh.

\section{KESIMPULAN}

Berdasarkan hasil penelitian karakteristik, pola pengobatan, dan efek samping pengobatan pasien leukemia limfoblastik akut di instalasi rawat inap RSUD Abdul Wahab Sjahranie periode 2014-2015 dapat disimpulkan sebagai berikut : 
1. Karakteristik berdasarkan jenis kelamin terbanyak adalah laki-laki sebanyak 13 kasus dengan persentase $62 \%$, berdasarkan usia terbanyak pada usia 0-4 tahun sebanyak 10 kasus dengan persentase $48 \%$ dan berdasarkan tipe LLA yang paling banyak diderita pasien adalah LLA tipe $\mathrm{L}_{1}$ sebanyak 13 kasus dengan persentase $62 \%$.

2. Pola pengobatan kemoterapi berdasarkan pemilihan jenis dan golongan obat kemoterapi terbanyak adalah Vincristine sebanyak 4 kasus dengan persentase $19 \%$ dan kombinasi obat Vincristine-Methotrexate sebanyak 4 kasus dengan persentase $19 \%$, sedangkan obat adjuvan terbanyak yang digunakan adalah Dexamethasone sebanyak 5 kasus dengan persentase $24 \%$.

3. Efek samping pengobatan kemoterapi terbanyak adalah mual muntah-anemia sebanyak 4 kasus dengan persentase $19 \%$.

\section{DAFTAR PUSTAKA}

Anderson, Philip O., dkk. 2002. Handbook of Clinical Drug Data tenth edition. McGrawHill Medical Publishing Division: New York

Aziz, F.M. 2002. Skrining dan Deteksi Dini Kanker Serviks. Balai Penerbit FKUI: Jakarta

Ball, Edward D. \& Kagan, Alex. 2013. 100 Questions \& Answers About Leukemia third edition. Jones \& Bartlett Learning: Burlington

ENCCA. 2014. Common Guidelines for Diagnostic Approaches to Leukemias. Seventh Framework Programme: Europe

Kemenkes RI. 2015. Situasi Penyakit Kanker. Kementerian Kesehatan Republik Indonesia: Jakarta

LLS. 2014. The ALL Guide: Information for Patients and Caregivers Acute Lymphoblastik Leukemia. AMGEN \& Jazz Pharmaceuticals: USA \& Ireland.

Pertiwi, N.M.I., Niruri, R., Ariawati, K. 2013. Gangguan Hematologi Akibat Kemoterapi pada Anak dengan Leukemia Limfositik Akut di Rumah Sakit Umum Pusat Sanglah. Jurnal Farmasi Udayana volume 2 nomor 3 